Proc. Estonian Acad. Sci. Geol., 1999, 48, 1, 15-34

\title{
DIAGENETIC TRANSFORMATION OF CLAY MINERALS IN LOWER CAMBRIAN ARGILLACEOUS SEDIMENTS OF NORTH ESTONIA
}

\author{
Kalle KIRSIMÄE ${ }^{\mathrm{a}}$, Volli KALM ${ }^{\mathrm{a}}$, and Per JØRGENSEN ${ }^{\mathrm{b}}$
}

a Institute of Geology, University of Tartu, Vanemuise 46, 51014 Tartu, Estonia; arps@math.ut.ee

b Department of Soil and Water Sciences, Agricultural University of Norway, B.P. 5028, 1432 Aas, Norway

Received 9 March 1998, in revised form 1 September 1998

\begin{abstract}
Clay mineral diagenesis in the Lower Cambrian sediments of the Lontova and Lükati formations in North Estonia, accompanying the main process of illite neoformation, was studied by means of X-ray powder diffraction. Fe-rich chlorite as well as microcrystalline quartz are typically diagenetic byproducts in the clay fraction, formed during illitization. Higher contents of kaolinite and of very fine clay subfraction $(<0.06 \mu \mathrm{m})$, consisting of only diagenetically formed minerals, in the silty sediments of the Lükati Formation are probably a result of meteoric water influx.
\end{abstract}

Key words: diagenesis, chlorite, kaolinite, Cambrian, Estonia.

\section{INTRODUCTION}

Diagenetic transformations of clay minerals in argillaceous sediments have been thoroughly studied for more than 30 years, since the studies by Burst (1959), Shutov et al. (1969), and Perry \& Hower (1970). Illitization, in particular, has been documented in various geological settings, including burial diagenetic environments (e.g. Hower et al., 1976; Boles \& Franks, 1979; Glassman et al., 1989; Lanson \& Champion, 1991; Eberl, 1993). So far main attention has been paid to clay diagenesis in relatively young, Mesozoic and Cenozoic palaeobasins of the Gulf Coast and elsewhere (e.g. Hower et al., 1976; Pearson \& Small, 1988; Renac \& Meunier, 1995), with generally high burial and subsidence rates, while diagenetic transformations in unmetamorphozed, older, Precambrian and Early Palaeozoic sediments are not so well documented. Nevertheless, in recent years some data on such systems have been published (Morad, 1983; Gorokhov et al., 1994, 1997; Gharrabi \& Velde, 1995; Li et al., 1995; Hover et al., 1996). 
The Lower Cambrian clayey sediments on the East European Platform, and particularly in Estonia, represent a unique complex of unmetamorphozed and nontectonized clays. In terms of burial depth and palaeotemperatures, these sediments have never passed the early diagenetic stage of sediment development (Einsele, 1992). Therefore, these sediments are useful in studies of the diagenetic changes other than those related to increasing burial depth and temperature (Hower et al., 1976; Pollastro, 1993). Other factors, such as initial composition of sediments (Freed \& Peacor, 1989), water/rock ratio and $\mathrm{K}^{+}$concentration (Whitney, 1990), and reaction time (Pytte \& Reynolds, 1989), become more important. A wide range of different mineralogical aspects of the Lower Cambrian clastic sediments, including clay minerals, has been studied by many authors (Reier, 1965a, 1965b; Pirrus, 1970, 1981, 1983; Mens \& Pirrus, 1977; Kallaste \& Pirrus, 1994). Indications of illite diagenesis in these sediments were documented by Vikulova (1949), Dilaktorski (1956), Reier (1965a, 1967), and Firsov et al. (1971), who used transmission electron microscopy to differentiate between two main morphological types of illite particles: elongated lath-shaped, and isometric (euhedral), which were interpreted as diagenetically formed. The continuous low-temperature diagenetic evolution of illitic minerals in the Lower Cambrian clayey sediments was recently investigated by Gorokhov et al. (1994) and Kirsimäe et al. (1999). However, probable diagenetic changes in nonclay silicates (tectosilicates) and other phyllosilicates have not yet been described.

The purpose of this study was to document the diagenetic changes in the clay and tectosilicate mineral assemblage of the Lower Cambrian Lontova and Lükati formations (Fms.) in northern Estonia. Both formations consist of clays and silty clays, and have probably undergone similar diagenetic processes, despite a stratigraphic unconformity between them (Mens \& Pirrus, 1977).

\section{GEOLOGICAL SETTING}

The study area, northern Estonia, lies in the northern part of the Baltic palaeobasin, in the northwestern region of the East European Platform (Fig. 1). The Lower Cambrian clays range in the Vendian through Tremadocian clastic sediments with a thickness of about 100 m (Mens \& Pirrus, 1997b). On the basis of lithological and palaeontological characteristics the Lower Cambrian sediments are divided into eight formations, but in northern Estonia the lowermost and uppermost beds of the Lower Cambrian are missing. In the northwestern part of the area the silty and sandy deposits of the near-shore facies represent the Voosi, Sõru, Lükati, Tiskre, Soela, and Irbeni Fms.; in the central and eastern parts only three formations, the Lontova, Lükati, and Tiskre Fms., make up the Lower Cambrian succession (Mens \& Pirrus, 1997a). The Lontova Fm. consists mostly of fine-grained unlithified clays and represents the 
maximum transgressional series, lithologically defined as the Mahu and Kestla members (Mbs.). Silty clays, loosely cemented sandstones and siltstones of the lowermost Sämi and uppermost Tammneeme Mbs. of the Lontova Fm. are from the beginning of the Lontova transgression and the end of the regressional stage, respectively. Towards western Estonia, the clayey Lontova Fm. grades into the siltstones and sandstones of the Voosi Fm. (Kala et al., 1981). The Lükati Fm., consisting of shallow-water, rhythmically interbedded clay and siltstones, overlies unconformably the Lontova Fm.

Palaeoburial temperatures in Lower Palaeozoic deposits were estimated by the thermal alteration of conodonts and acritarch organic material, with particular attention to the Lower Cambrian sediments of Baltoscandia (Bergström, 1980; Moczydłowska \& Vidal, 1986; Hagenfeldt, 1996). The Cambrian sediments in the Mjøsa and Oslo regions, Norway, have undergone tectonic deformation and thermal alteration at temperatures between 150 and $200{ }^{\circ} \mathrm{C}$ during the Caledonian orogeny, while in eastern Sweden and western Finland burial temperatures were below $50{ }^{\circ} \mathrm{C}$. There is no systematic data on microfossils or vitrinite thermal alterations in the Cambrian sediments of Estonia. However, well-preserved paletransparent acritarch palynomorphs indicate little, if any, thermal alteration in these sediments (Ivo Paalits, pers. comm.). The acritarch thermal alteration index (Hayes et al., 1983) from the Lükati Fm. in Kopli quarry has been estimated to be about 1 (Nina Talyzina, pers. comm.), which indicates temperatures of less than $50{ }^{\circ} \mathrm{C}$. This estimate supports previous conclusions drawn on sedimentological and thermal data that the maximum overburden of the Lower Cambrian sediments in northern Estonia could reach $800-1000 \mathrm{~m}$ and the palaeotemperature probably did not exceed $35^{\circ} \mathrm{C}$ (Kirsimäe et al., 1999).

\section{MATERIAL AND METHODS}

Twenty-three samples were investigated, representing the geographic distribution of the clayey Lower Cambrian sequence in northern Estonia. Both major lithological units, the Lükati and Lontova Fms., were sampled. From the Lontova Fm., only samples representing the two uppermost members (Tammneeme and Kestla), available also in outcrops and quarries, were included. The westernmost drillcores studied, F333 and F344 (Fig. 1), are located in the zone where the clays of the Lontova Fm. grade into the silt- and sandstones of the Voosi Fm. However, typical lithological characteristics of the clayey uppermost members of the Lontova Fm. have been recorded in drillcores beyond the western boundary of the distribution of the Lontova Fm. (Kala et al., 1981). In our study we use the lithostratigraphical subdivision of K. Mens and E. Pirrus for these drillcores (Geological Survey of Estonia, unpubl. report). According to this subdivision, the Lontova Stage samples from drillcores F333 and F344 belong to the Lontova Fm. and the Voosi Fm., respectively. 


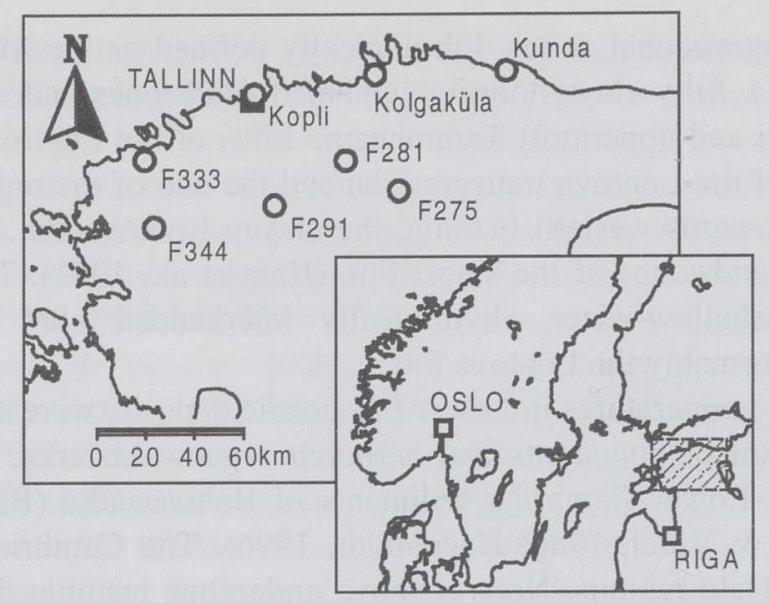

Fig. 1. Location of the studied quarries and drillcores.

The samples were dispersed in distilled water with sodium hexametaphosphate. Occasional stirring and short ultrasonic treatment ( $70 \mathrm{~W}, 2 \mathrm{~min}$ ) with probe were used to facilitate the dispersion. The dispersed samples were separated by combination of standard wet-sieving and gravity sedimentation procedures (Griffiths, 1967) into the following grain size fractions: $<2,2-6$, $6-20,20-63,63-125$, and $125-250 \mu \mathrm{m}$ for samples from the $\mathrm{K} 1-\mathrm{K} 10$ series and $<2,2-6,6-20,20-63$, and $>63 \mu \mathrm{m}$ for samples in the A1-A13 series. The $<2 \mu \mathrm{m}$ fractions of 13 samples were separated into four subfractions $(2-0.6,0.6-0.2$, $0.2-0.06$, and $<0.06 \mu \mathrm{m}$ ) by using ultra-centrifugation (Jackson, 1969). The finest subfraction $(<0.06 \mu \mathrm{m})$ was flocculated using $1 \mathrm{~N} \mathrm{CaCl}_{2}$ or $1 \mathrm{~N} \mathrm{NaCl}$ and washed with distilled water to remove excess salt.

The mineralogical composition of two fractions, $<2 \mu \mathrm{m}$ and $2-6 \mu \mathrm{m}$, from all samples was studied by means of X-ray powder diffraction (XRD). The $<2 \mu \mathrm{m}$ fraction containing suspension was flocculated and subsequently $\mathrm{Mg}^{2+}$ exchanged overnight with $1 \mathrm{M} \mathrm{MgCl}_{2}$ prior to the slide preparation. The compositions of coarse fractions (6-20, 20-63, and $>63 \mu \mathrm{m})$ and of bulk rock were also analysed by XRD. Coarse fractions and whole-rock samples were wet-crushed in a micronizing mill prior to the preparation of X-ray slides. The XRD slides were obtained by sedimentation onto a porous porcelain plate under pressure or by smearing on a glass slide (subfractions of the $<2 \mu \mathrm{m}$ material). Conventional treatments with $10 \% \mathrm{HCl}\left(80^{\circ} \mathrm{C}, 2 \mathrm{~h}\right)$, solvation in ethylene glycol vapour $\left(60{ }^{\circ} \mathrm{C}, 48 \mathrm{~h}\right)$, and a heat treatment $\left(525^{\circ} \mathrm{C}, 2 \mathrm{~h}\right)$ were used to verify the mineral identification and estimate the semiquantitative proportions. X-ray diffractograms were obtained using a Phillips 1710 diffractometer equipped with a graphite monochromator, $\mathrm{Cu} K \alpha$ radiation, and a DRON $3 \mathrm{M}$ diffractometer with $\mathrm{Ni}$-filtered $\mathrm{Cu} K \alpha$ radiation at room temperature $\left(20^{\circ} \mathrm{C}\right)$. The XRD patterns were 
recorded digitally with $0.02{ }^{\circ} 2 \Theta$ step size and 3 or $4 \mathrm{~s}$ of counting time per step. Mineral identification criteria were based on Brown \& Brindley (1980), Reynolds (1985), and Moore \& Reynolds (1989). To estimate the semiquantitative mineral composition, peak intensities of chlorite $(14 \AA)$, mixed-layered illite-smectite (I/S) $(10-14 \AA)$, illite $(10 \AA)$, kaolinite $(7 \AA)$, quartz (4.26 $\AA$ ), K-feldspar $(3.94 \AA)$, and hematite/pyrite $(2.70 \AA)$ were multiplied by factors of $1.1,1,2,1,4,16$, and 3 , respectively (Pederstad \& Jørgensen, 1985; Islam \& Lotse, 1986). A factor of 3 for the hematite peak at $2.70 \AA$ was selected assuming a partial orientation of the presumable platy hematite crystals. Due to extensive overlapping with other peaks, we could not use the $3.25 \AA$ peak for K-feldspar estimation, which was thus replaced by the four times weaker $3.94 \AA$ reflection. Kaolinite 001 peak intensity was estimated in two independent ways: (1) by assuming that the $7 \AA$ (001) peak is 10 times stronger than the $2.38 \AA$ (003) peak, and (2) by measuring the $7 \AA$ peak after $\mathrm{HCl}$ treatment. Although these methods are in good agreement, we encountered occasional problems with an overlapping peak from the ceramic plate at $2.38 \AA$. Rare occurrences of dolomite and albite were not quantified. The semiquantitative mineral composition was verified against the wet chemical analysis of the $<2 \mu \mathrm{m}$ fraction of selected samples (Table 1 ).

The XRD curves of air-dried and ethylene glycol treated $<2 \mu \mathrm{m}$ subfractions were decomposed in the $5-12{ }^{\circ} 2 \Theta$ region into elementary XRD bands, according to the criteria given by Lanson (1997), with WinFit (Krumm, 1994) and AXES (Mändar et al., 1996) decomposition software. Background stripped and Lorentz polarization factor corrected curves were fitted for I/S and poorly crystallized illite (PCI) with a Gaussian, and for well-crystallized illite (WCI) and chlorite with a Lorentzian peak shape models. Each elementary band was characterized by the position, maximum intensity, and full width at half maximum (FWHM) intensity parameters. The reliability of decomposition results was checked against the NEWMOD ${ }^{\oplus}$ (Reynolds, 1985) modelled XRD curves.

\section{RESULTS AND DISCUSSION}

\section{Grain size data}

Figure 2 illustrates the typical grain size distribution of the samples. The samples from the Kestla $\mathrm{Mb}$. represent the maximum transgression stage in the succession. These are clays with more than $50 \%$ material finer than $2 \mu \mathrm{m}$ and a high fine to medium silt content (Fig. 2B). The samples from the Tammneeme $\mathrm{Mb}$. and from the Lükati Fm., representing the regressive part of Lontova time and the following Dominopol' transgression stages, respectively, have a bimodal grain size distribution with maximums in the clay and medium to coarse silt fractions (Fig. 2A). These results agree well with the previously published grain size data on Lower Cambrian clays of northern Estonia (e.g. Pirrus \& Saarse, 1979). 


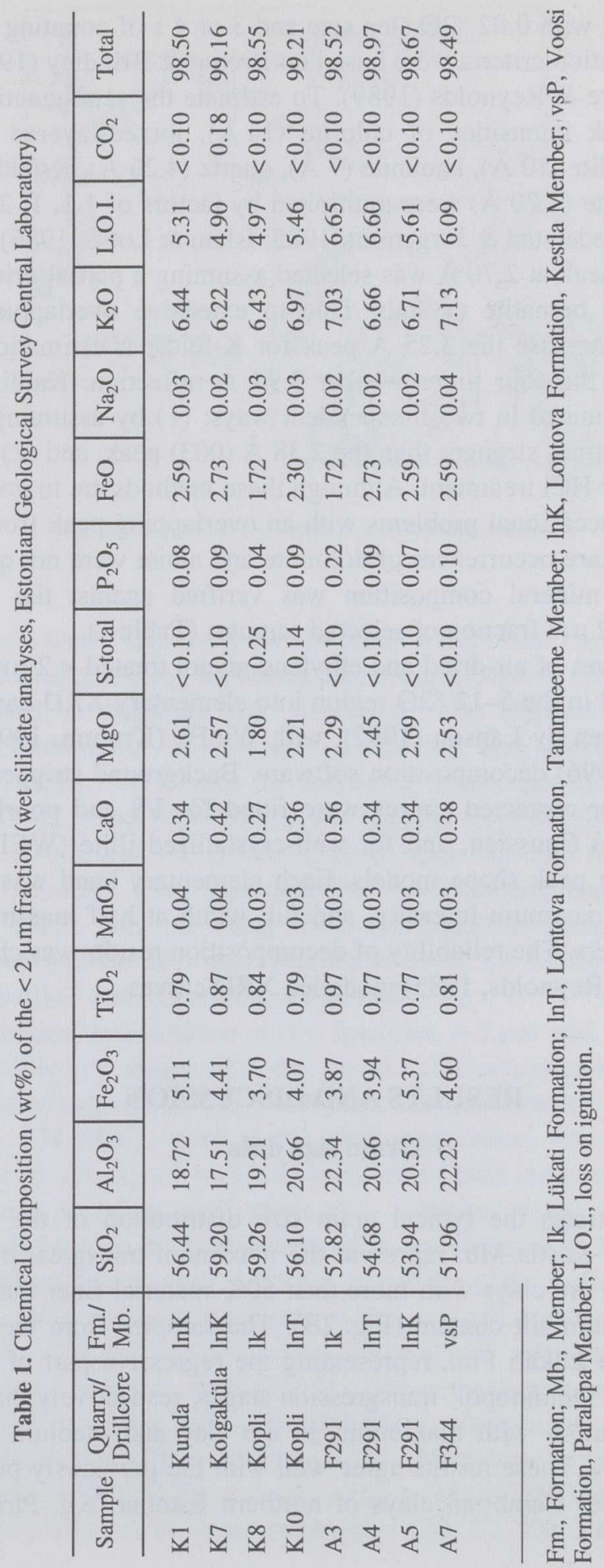



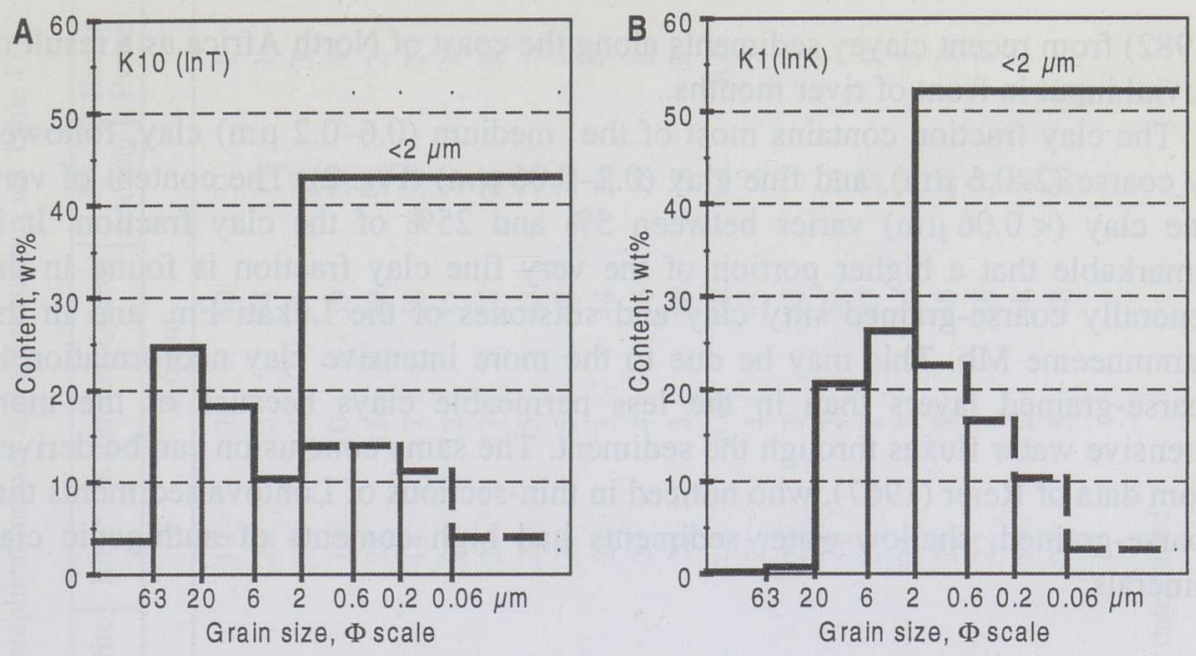

Fig. 2. Histograms illustrating the typical grain size distribution of the samples studied. The contents of the subfractions in the $<2 \mu \mathrm{m}$ fraction are shown with a dashed line. See Table 1 for stratigraphical indexes.

From the sedimentological point of view, the bulk sediment composition could be explained as a mixture of two modes composed of coarse silt and fine sand $(>20 \mu \mathrm{m})$, and of clay and fine to medium silt (Fig. 3). This mixture is easily eroded and transported by submarine currents and by wave action (Jørgensen et al., 1981). These modes represent probably suspension load material, transported as single particles, and clay mineral flocs/aggregates, respectively. Similar bimodal grain size distributions were described by Lange

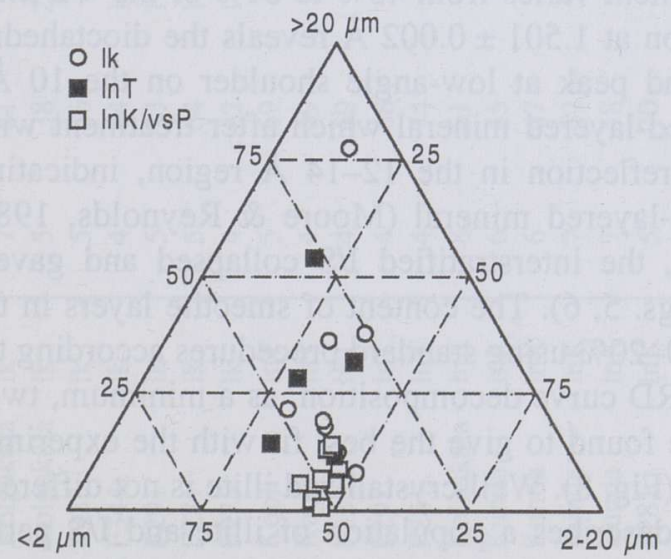

Fig. 3. Ternary diagram illustrating variations in grain size composition. See Table 1 for stratigraphical indexes. 
(1982) from recent clayey sediments along the coast of North Africa as a result of fluvial input in front of river mouths.

The clay fraction contains most of the medium $(0.6-0.2 \mu \mathrm{m})$ clay, followed by coarse $(2-0.6 \mu \mathrm{m})$, and fine clay $(0.2-0.06 \mu \mathrm{m})$ (Fig. 2$)$. The content of very fine clay $(<0.06 \mu \mathrm{m})$ varies between $5 \%$ and $25 \%$ of the clay fraction. It is remarkable that a higher portion of the very fine clay fraction is found in the generally coarse-grained silty clay and siltstones of the Lükati Fm. and in the Tammneeme $\mathrm{Mb}$. This may be due to the more intensive clay neoformation in coarse-grained layers than in the less permeable clays because of the more intensive water fluxes through the sediment. The same conclusion can be derived from data of Reier (1967), who noticed in thin-sections of Lontova sediments that coarse-grained, shallow-water sediments had high contents of authigenic clay minerals.

\section{Mineral composition}

The sediments are characterized by illite-chlorite-kaolinite clay mineral assemblages, with additional tectosilicates (quartz and feldspars), some hematite or pyrite, and, less frequently, dolomite (Table 2). As a rule, the clay mineral content decreases from finer to coarser fractions, while the amount of nonclay minerals increases. The $>63 \mu \mathrm{m}$ fractions contained only quartz and $\mathrm{K}$-feldspar with some traces of phyllosilicates from sand-size mica and glauconitic pellets. The composition of the $2-6$ and $<2 \mu \mathrm{m}$ fractions, of both the Lontova and Lükati Fm. sediments, are quite similar, although the Lükati Fm. sediments contain more kaolinite (Table 2, Fig. 4). Figures 5-7 show the typical XRD diffraction curves of the $<2$ and $2-6 \mu \mathrm{m}$ fractions, and of the four subfractions separated within the $<2 \mu \mathrm{m}$ clay. The illitic minerals are the most abundant ones in all the samples analysed. Their content varies from $45 \%$ to $81 \%$ of the $<2 \mu \mathrm{m}$ fraction, and the $d(060)$ peak position at $1.501 \pm 0.002 \AA$ reveals the dioctahedral nature of these minerals. The broad peak at low-angle shoulder on the $10 \AA$ peak shows the presence of a mixed-layered mineral which after treatment with ethylene glycol produces a broad reflection in the $12-14 \AA$ region, indicating a highly illitic ordered I/S mixed-layered mineral (Moore \& Reynolds, 1989). After heating for $2 \mathrm{~h}$ at $525^{\circ} \mathrm{C}$, the interstratified I/S collapsed and gave a sharp peak at $10.02 \pm 0.02 \AA$ (Figs. 5, 6). The content of smectite layers in the R1 ordered I/S was estimated at 10-20\% using standard procedures according to Środoń (1984).

By means of XRD curve decomposition, as a minimum, two illite phases and one I/S phase were found to give the best fit with the experimental XRD curve: I/S, PCI, and WCI (Fig. 8). Well-crystallized illite is not differentiated from mica. The term "phase" describes a population of illite and I/S particles with similar physicochemical characteristics as defined by Lanson \& Velde (1992). Thus, the decomposed diffraction band at $10.9-11.5 \AA$ with a large FWHM value $\left(>1.5^{\circ} 2 \Theta\right)$, which becomes displaced toward lower angles after treatment with ethylene 


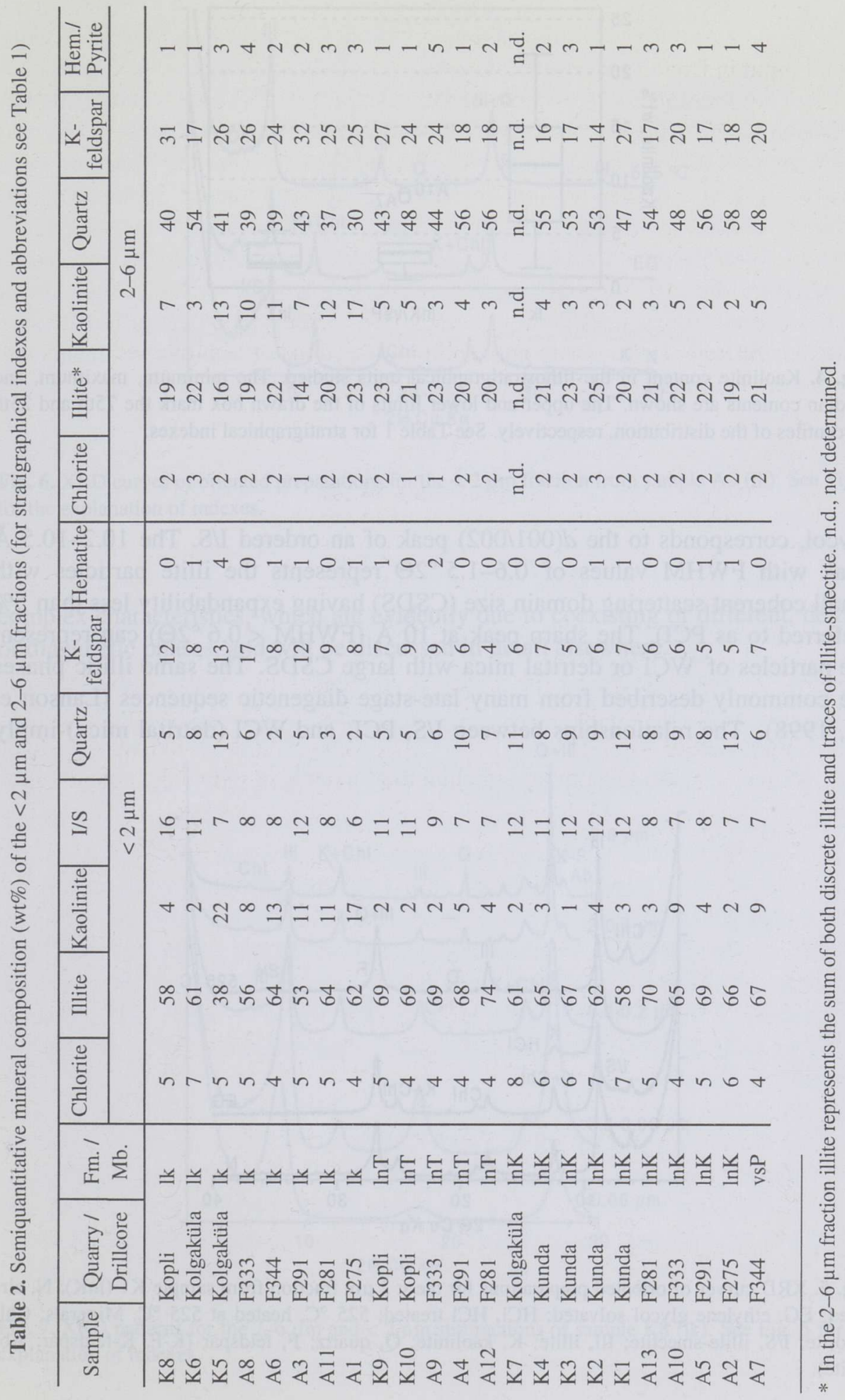




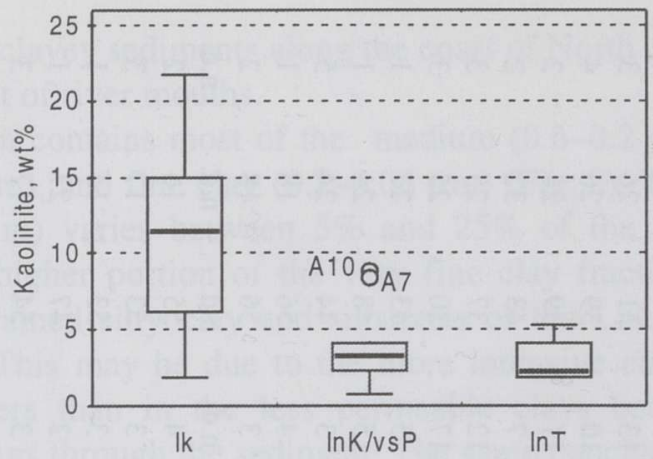

Fig. 4. Kaolinite content in the lithostratigraphical units studied. The minimum, maximum, and median contents are shown. The upper and lower limits of the drawn box mark the 75 th and 25 th percentiles of the distribution, respectively. See Table 1 for stratigraphical indexes.

glycol, corresponds to the $d(001 / 002)$ peak of an ordered I/S. The $10.2-10.5 \AA$ peak with FWHM values of $0.6-1.5^{\circ} 2 \Theta$ represents the illite particles with small coherent scattering domain size (CSDS) having expandability less than $5 \%$ (referred to as PCI). The sharp peak at $10 \AA$ (FWHM $<0.6^{\circ} 2 \Theta$ ) can represent the particles of WCI or detrital mica with large CSDS. The same illitic phases are commonly described from many late-stage diagenetic sequences (Lanson et al., 1998). The relationships between I/S, PCI, and WCI (detrital mica) imply

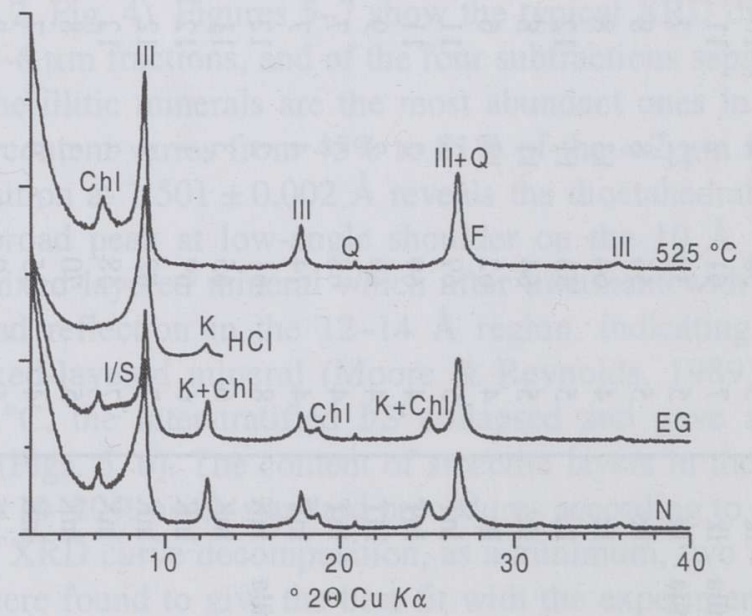

Fig. 5. XRD curves of oriented preparations for the $<2 \mu \mathrm{m}$ fraction from sample $\mathrm{K} 1$ ( $\operatorname{lnK}$ ): $\mathrm{N}$, airdried; EG, ethylene glycol solvated; $\mathrm{HCl}, \mathrm{HCl}$ treated; $525{ }^{\circ} \mathrm{C}$, heated at $525{ }^{\circ} \mathrm{C}$. Minerals: Chl, chlorite; I/S, illite-smectite; Ill, illite; K, kaolinite; Q, quartz; F, feldspar (K-F, K-feldspar; Ab, albite). 


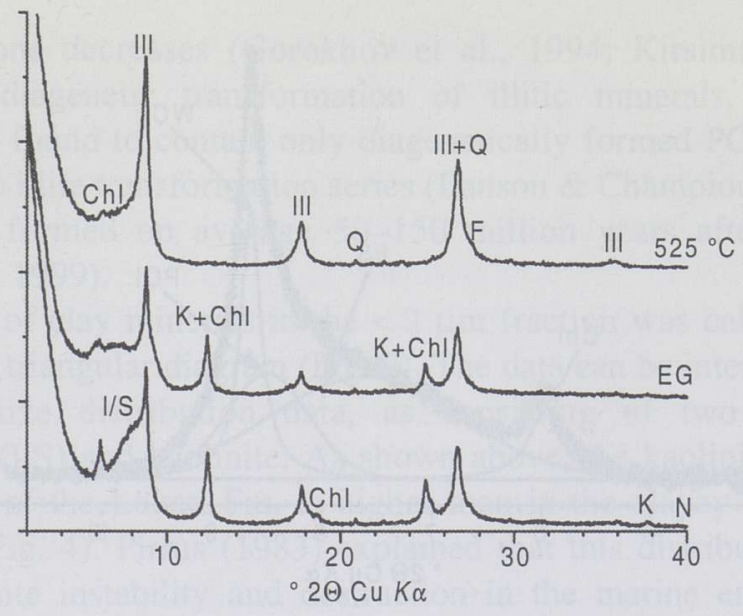

Fig. 6. XRD curves of oriented preparations for the $<2 \mu \mathrm{m}$ fraction from sample A3 (lk). See Fig. 5 for the explanation of indexes.

complex characteristics, which are evidently due to coexisting of different, detrital or diagenetic phases, and will be discussed in detail elsewhere.

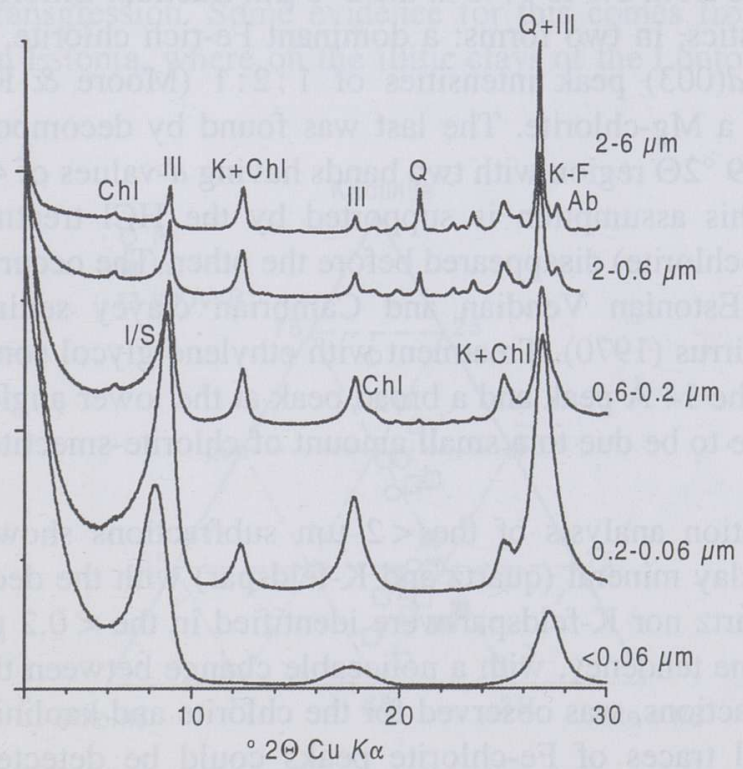

Fig. 7. XRD patterns for the $2-6 \mu \mathrm{m}$ and $<2 \mu \mathrm{m}$ subfractions of sample K8 (lk). See Fig. 5 for the explanation of indexes. 


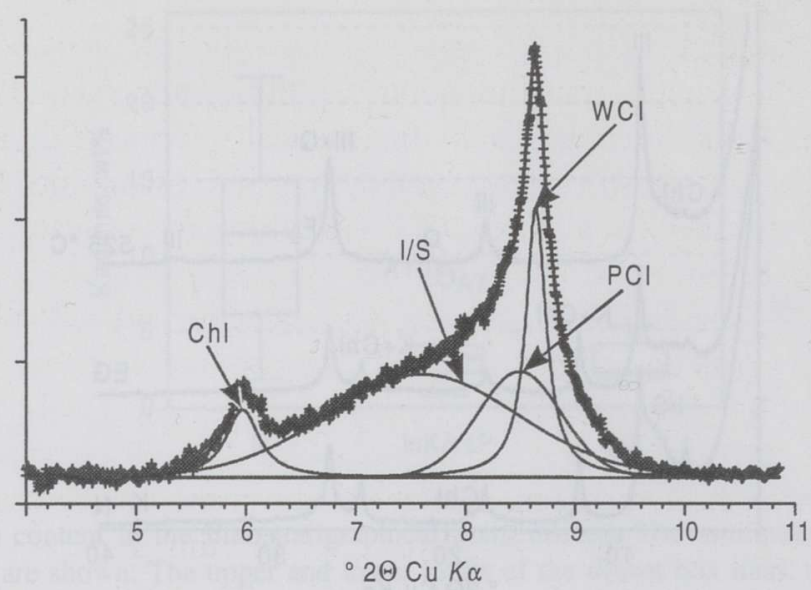

Fig. 8. Decomposition of air-dried XRD pattern of sample A13 (lnK). The experimental curve is shown with cross-marks and the fitted profile with a solid line. Chl, chlorite; I/S, illite-smectite; PCI, poorly crystallized illite; WCI, well-crystallized illite or detrital mica.

Chlorite and kaolinite occur as minor components in both mineral assemblages. The chlorite content ranges from $4 \%$ to $8 \%$ in the $<2 \mu \mathrm{m}$ fraction and from $1 \%$ to $3 \%$ in the $2-6 \mu \mathrm{m}$ fraction, while the kaolinite percentage varies from $1 \%$ to $22 \%$ in the $<2 \mu \mathrm{m}$ and from $2 \%$ to $17 \%$ in the $2-6 \mu \mathrm{m}$ fraction. Chlorite appears, from XRD characteristics, in two forms: a dominant Fe-rich chlorite, as indicated by $d(001): d(002): d(003)$ peak intensities of $1: 2: 1$ (Moore \& Reynolds, 1989) and as traces of a Mg-chlorite. The last was found by decomposing the $d(003)$ peak in the $18-19^{\circ} 2 \Theta$ region with two bands having $d$-values of $4.72-4.73 \AA$ and $4.76-4.77 \AA$. This assumption is supported by the $\mathrm{HCl}$ treatment, where the $4.76 \AA$ peak (Fe-chlorite) disappeared before the other. The occurrence of Fe-rich chlorite in the Estonian Vendian and Cambrian clayey sediments was also determined by Pirrus (1970). Treatment with ethylene glycol sometimes reduced the intensity of the $14 \AA$ peak and a broad peak at the lower angle side appeared, which we believe to be due to a small amount of chlorite-smectite mixed-layered mineral.

X-ray diffraction analysis of the $<2 \mu \mathrm{m}$ subfractions showed an apparent decrease in nonclay mineral (quartz and $\mathrm{K}$-feldspar) with the decreasing particle size. Neither quartz nor K-feldspar were identified in the $<0.2 \mu \mathrm{m}$ subfractions (Fig. 7). The same tendency, with a noticeable change between the 0.2-0.06 and $<0.06 \mu \mathrm{m}$ subfractions, was observed for the chlorite and kaolinite distributions. Only very small traces of Fe-chlorite peaks could be detected in the finest $(<0.06 \mu \mathrm{m})$ fraction. The remaining major components in these subfractions are illite and I/S. With the decreasing particle size the content of I/S and PCI increases (Kirsimäe et al., 1999), while the apparent $\mathrm{Rb} / \mathrm{Sr}$ isotope age for the 
same subfractions decreases (Gorokhov et al., 1994; Kirsimäe et al., 1999), reflecting the diagenetic transformation of illitic minerals. The $<0.06 \mu \mathrm{m}$ subfraction was found to contain only diagenetically formed PCI and I/S phases from smectite to illite transformation series (Lanson \& Champion, 1991) and they were probably formed on average 50-150 million years after sedimentation (Kirsimäe et al., 1999).

The content of clay minerals in the $<2 \mu \mathrm{m}$ fraction was calculated to $100 \%$ and plotted in a triangular diagram (Fig. 9). The data can be interpreted, similarly to the grain size distribution data, as consisting of two assemblages chlorite + illite (I/S) and kaolinite. As shown above, the kaolinite content in the silty sediments of the Lükati Fm. is higher than in the clayey sediments of the Lontova Fm. (Fig. 4). Pirrus (1983) explained that this distribution occurs as a result of kaolinite instability and destruction in the marine environment. This conflicts with several studies where kaolinite is found to be stable under normal marine conditions (e.g. Robert \& Chamley, 1987). The simplest possible explanation could be the differential settling of clay minerals in a sea basin. Usually, the kaolinite with a larger particle size becomes concentrated close to river mouths, while the small-size smectite particles are transported farther to the basin (Gibbs, 1977). However, the geological data available suggests also other possibilities that should be discussed. First, during the hiatus between the Lontova and Lükati Fms., a kaolinitic weathering crust developed on the Lontova sediments in northern Estonia and was extensively eroded and redeposited during the following transgression. Some evidence for this comes from central Latvia and southeastern Estonia, where on the illitic clays of the Lontova Fm. the partly

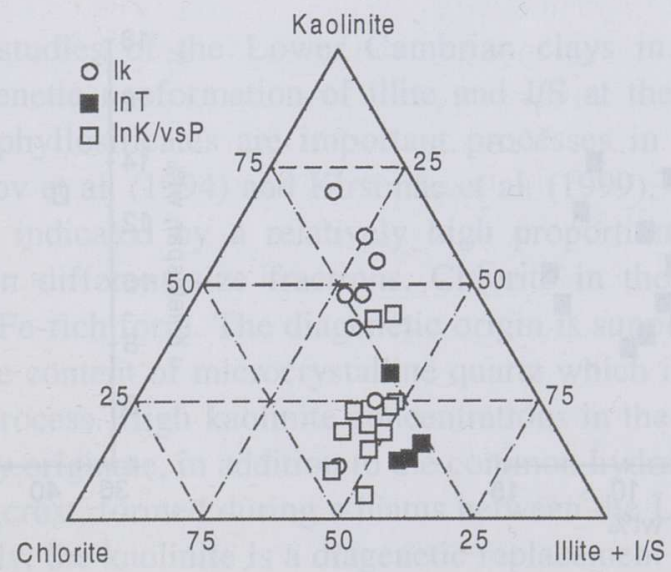

Fig. 9. Clay mineral composition of the $<2 \mu \mathrm{m}$ fraction. The illite $+\mathrm{I} / \mathrm{S}$ content is divided by a factor of 10 to make the changes more visible. See Table 1 for stratigraphical indexes. 
preserved weathering crust with high kaolinite has been reported (Brangulis et al., 1978; Mens \& Pirrus, 1997a). However, the possible timing of this weathering event is yet not clear as the Lükati Fm. is apparently missing in the sections there and the weathering traces extend northwards to the top of the Lükati sediments. Second, the kaolinitization may have been highly probable in this section due to meteoric influx during the discontinuous sedimentation in the Middle to Late Cambrian (Mokrik, 1997). The authigenic kaolinite may form at the expense of detrital mica (Bjørlykke \& Brendstal, 1986) or K-feldspar (Hugget, 1996; Lanson et al, 1996) during very early diagenesis at temperatures as low as $25-50{ }^{\circ} \mathrm{C}$ (Osborne et al., 1994). Moreover, the kaolinitization is preferentially related to the subsurface leaching of the permeable sediments such as sandstones, where the process is controlled by $\mathrm{H}^{+}$supply and the $\mathrm{K}^{+} / \mathrm{H}^{+}$activity ratio (Hugget, 1996). This idea is also supported by our preliminary results, which suggest that the authigenic kaolinite and illite formation is an important diagenetic process in the Lower Cambrian kaolinite-rich sandstones of the Voosi Fm., which is the Lontova Fm. equivalent in western Estonia. The diagenetic formation of kaolinite may explain, in addition to the simple physical segregation, the distribution pattern of this mineral, closely related to coarser sediments of the near-shore facies.

Chlorite was probably formed during the main illitization process in the Lower Cambrian sediments. Fe-rich chlorite, which predominates here, is commonly formed in diagenetic environments (Curtis et al., 1985; Hillier \& Velde, 1991), whereas Mg-chlorite is normally formed only in metamorphic environments (Laird, 1988). The chlorite appears as a reaction byproduct during

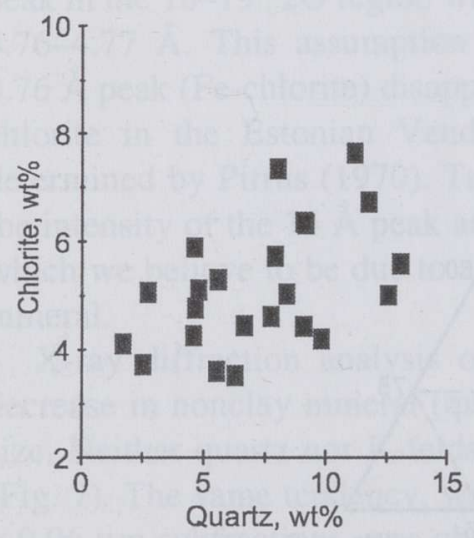

Fig. 10. Correlation between chlorite and microcrystalline quartz contents in the $<2 \mu \mathrm{m}$ fraction.

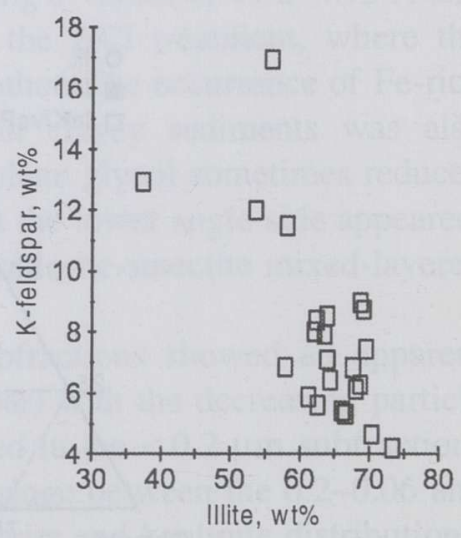

Fig. 11. Correlation between illite and Kfeldspar contents in the $<2 \mu \mathrm{m}$ fraction. 
illitization, utilizing released iron and magnesium (Hower et al., 1976; Boles \& Franks, 1979). Moreover, chlorite formation in Cambrian sediments is strongly supported by the occurrence of mixed-layered chlorite-smectite in the clay fraction which forms if the chlorite precipitates within the precursor smectite or I/S (Ahn \& Peacor, 1985). The mineralogical changes determined in this reaction: smectite $(\mathrm{I} / \mathrm{S})+\mathrm{K}$-feldspar + mica $\rightarrow$ illite + quartz + chlorite + (albite) suggest simultaneous precipitation of secondary microcrystalline quartz. This may explain the positive correlation between chlorite and quartz contents in the $<2 \mu \mathrm{m}$ fraction (Fig. 10). Neoformation of microcrystalline quartz will result in an increase in the quartz content with the decreasing particle size, which is the opposite of what is normally found for clastic sediments. The same illitization reaction is probably the reason for the negative correlative dependence between illite (PCI and WCI) and K-feldspar contents in the $<2 \mu \mathrm{m}$ fraction, which may indicate a gradual dissolution of a K-feldspar and illite formation (Fig. 11). Small amounts of albite, which can also form in this reaction, were detected only in the 2-6 $\mu \mathrm{m}$ and $0.6-2 \mu \mathrm{m}$ fractions. This means that albite is present as fine-grained discrete crystallites and not as a perthitic component in a K-feldspar matrix. Otherwise, the albite should also occur in the coarser fractions with higher $\mathrm{K}$-feldspar contents. Nevertheless, diagenetic formation of albite is not the only plausible way to explain this grain size distribution for albite. It may also be inherited from the sediment source areas or derived from the disintegration of perthitic microcline (Kallaste \& Pirrus, 1994).

\section{CONCLUSIONS}

Mineralogical studies of the Lower Cambrian clays in northern Estonia revealed that diagenetic neoformation of illite and I/S at the expense of older tectosilicates and phyllosilicates are important processes in the sediments, as shown by Gorokhov et al. (1994) and Kirsimäe et al. (1999). The importance of these processes is indicated by a relatively high proportion of diagenetically formed minerals in different size fractions. Chlorite in these sediments is a typical diagenetic Fe-rich form. The diagenetic origin is supported by a positive correlation with the content of microcrystalline quartz which is also a byproduct of the illitization process. High kaolinite concentrations in the silty sediments of the Lükati Fm. may originate, in addition to the common hydraulic sorting, either from a weathering crust, formed during a hiatus between the Lontova and Lükati Fms. or, more likely, the kaolinite is a diagenetic replacement of old $\mathrm{K}$-feldspars and mica due to influx of meteoric water. This influx was most important in the silty interlayers with favourable permeabilities and water/rock ratios between compact clays. 


\section{ACKNOWLEDGEMENTS}

We appreciate the financial support from Amerada Hess A/S and The Norwegian Academy of Science and Letters. Thanks are extended to K. Mens, R. Szava-Kovats, E. Pirrus, and an anonymous referee for critical comments and helpful suggestions.

\section{REFERENCES}

Ahn, J. H. \& Peacor, D. R. 1985. Transmission electron microscopic study of diagenetic chlorite in Gulf Coast argillaceous sediments. Clays Clay Miner., 33, 228-236.

Bergström, S. M. 1980. Conodonts as paleotemperature tools in Ordovician rocks of the Caledonides and adjacent areas in Scandinavia and the British Isles. GFF, 102, 377-392.

Bjørlykke, K. \& Brendstal, A. 1986. Diagenesis of the Brent sandstone in the Statfjord field. In Roles of Organic Matter in Sedimentary Diagenesis (Gaultier, D. L., ed.). SEPM Spec. Publ., 38, 157-168.

Boles, J. F. \& Franks, S. G. 1979. Clay diagenesis in Wilcox sandstones of southwest Texas: implications of smectite diagenesis on sandstone cementation. J. Sedim. Petrol., 49, 55-70.

Brangulis, A., Nagle, A., Murnieks, A. \& Sokurenko, A. 1978. Regularities on the distribution of clay minerals in Upper Proterozoic and Cambrian terrigenous sequence in Latvia. In Ocherki geologii Latvii (Brangulis, A., ed.), pp. 87-97. Zinatne, Riga (in Russian).

Brown, G. \& Brindley, G. W. 1980. X-ray diffraction procedures for clay mineral identification. In Crystal Structures of Clay Minerals and Their X-ray Identification (Brindley, G. W. \& Brown, G., eds.), pp. 305-360. Mineralogical Society, Monograph No. 5., London.

Burst, J. F. 1959. Post diagenetic clay mineral-environment relationship in the Gulf Coast Eocene in clays and clay minerals. Clays Clay Miner., 6, 327-341.

Curtis, P. M., Hughes, C. R., Whiteman, J. A. \& Whittle, C. K. 1985. Compositional variation within some sedimentary chlorites and some comments on their origin. Miner. Mag., 49, $375-386$.

Dilaktorski, N. 1956. Über die physikalisch-chemischen Eigenschaften der feinen Fraktionen einiger Ton(erden) der Estnischen SSR. Eesti NSV TA Toim. Tehn. Fü̈̈s. Mat., 5, 1, 22-40 (in Russian).

Eberl, D. D. 1993. Three zones for illite formation during burial diagenesis and metamorphism. Clays Clay Miner., 41, 26-37.

Einsele, G. 1992. Sedimentary Basins. Evolution, Facies, and Sediment Budget. Springer-Verlag, Berlin.

Firsov, L., Nikolajeva, I., Lebedev, Y. \& Solntseva, S. 1971. Composition, origin and absolute age of micaceous minerals in Lower Cambrian blue clays of the Baltic Region. Trud. Inst. Geol. Geofiz., Sibirsk. Otdel. Akad. Nauk SSSR, 144, 165-192 (in Russian).

Freed, R. L. \& Peacor, D. R. 1989. Variability in temperature of the smectite/illite reaction in Gulf Coast sediments. Clay Miner., 24, 171-180.

Gharrabi, M. \& Velde, B. 1995. Clay mineral evolution in the Illinois Basin and its causes. Clay Miner., 30, 353-364.

Gibbs, R. J. 1977. Clay mineral segregation in the marine environment. J. Sedim. Petrol., 47, 237243.

Glassman, J. R., Larter, S., Briedis, N. A. \& Lundegard, P. D. 1989. Shale diagenesis in the Bergen High Area, North Sea. Clays Clay Miner., 37, 97-112. 
Gorokhov, I. M., Clauer, N., Turchenco, T. L., Melnikov, N. N., Kutyavin, E. P., Pirrus, E. \& Baskakov, A. V. 1994. Rb-Sr systematics of Vendian-Cambrian claystones from the East European Platform: implications for a multi-stage illite evolution. Chem. Geol, 112, 71-89.

Gorokhov, I. M., Melnikov, N. N., Turchenco, T. L. \& Kutyavin, E. P. 1997. Rb-Sr systematics of clay fractions in Lower-Riphean argillites: Ust-Il'inskaya Formation, Anabar Massif, northern Siberia. Litol. Polezn. Iskopaemye, 5, 530-539 (in Russian).

Griffiths, J. C. 1967. Scientific Method in Analysis of Sediments. McGraw-Hill, New York.

Hagenfeldt, S. 1996. Lower Palaeozoic acritarchs as indicators of heat flow and burial depth of sedimentary sequences in Scandinavia. In Acritarcha in Praha 1996 (Fatka, O. \& Servais, T., eds.). Acta Universitatis Carolinae. Geologica, 40, 413-424.

Hayes, J. M., Kaplan, I. R. \& Wedekning, K. M. 1983. Precambrian organic geochemistry, preservation of the record. In Earth's Earliest Biosphere, its Origin and Evolution (Schopf, J. W., ed.), pp. 93-134. Princeton University Press.

Hillier, S. \& Velde, B. 1991. Composition of diagenetic chlorites. Clay Miner., 26, 149-168.

Hover, V. C., Peacor, D. R. \& Lynn, M. W. 1996. STEM/AEM evidence for preservation of burial diagenetic fabrics in Devonian shales: implications for fluid/rock interaction in cratonic basins (U.S.A.). J. Sedim. Petrol., 66, 519-530.

Hower, R. J., Eslinger, E. V., Hower, M. E. \& Perry, E. A. 1976. Mechanisms of burial metamorphism of argillaceous sediment: 1. Mineralogical and chemical evidence. Geol. Soc. Amer. Bull., 87, 725-737.

Hugget, J. M. 1996. Alumosilicate diagenesis in a Tertiary sandstone-mudrock sequence from the central North-Sea, UK. Clay Miner., 31, 523-536.

Islam, A. K. M. E. \& Lotse, E. G. 1986. Quantitative mineralogical analysis of some Bangladesh soils with X-ray, ion exchange and selective dissolution techniques. Clay Miner., 21, $31-42$.

Jackson, M. L. 1969. Soil Chemical Analysis - Advanced Course. 2nd Edition. Published by the author, Madison, Wisconsin.

Jørgensen, P., Erlenkeuser, H., Lange, H., Nagy, J., Rumorh, J. \& Werner, F. 1981. Sedimentological and stratigraphical studies of two cores from the Skagerrak. Spec. Publ. Int. Ass. Sediment., 5, 397-414.

Kala, E., Kajak, K., Mens, K. \& Pirrus, E. 1981. Lithostratigraphy and facies of the Lontova Stage in Estonia. Eesti NSV TA Toim. Geol., 30, 4, 137-147 (in Russian).

Kallaste, T. \& Pirrus, E. 1994. Feldspars in the terrigenous sedimentary rocks of Estonia according to X-ray structural analysis. Proc. Estonian Acad. Sci. Geol., 43, 1, 38-45.

Kirsimäe, K., Jørgensen, P. \& Kalm, V. 1999. Low temperature illite-smectite in Lower Cambrian clays, North Estonia. Clay Miner., 34 (in press).

Krumm, S. 1994. WinFit1.0 - A public domain program for interactive profile-analysis under Windows. Acta Universitatis Carolinae. Geologica, 38, 253-261.

Laird, J. 1988. Chlorites: metamorphic petrology. In Hydrous Phyllosilicates (Exclusive of Micas) (Bailey, S. W., ed.). Reviews in Mineralogy, 19, 405-447.

Lange, H. 1982. Distribution of chlorite and kaolinite in eastern Atlantic sediments off North Africa. Sedimentology, 29, 427-431.

Lanson, B. 1997. Decomposition of experimental X-ray diffraction patterns (profile fitting): a convenient way to study clay minerals. Clays Clay Miner., 45, 132-146.

Lanson, B. \& Champion, D. 1991. The I/S-to-illite reaction in the late stage diagenesis. Am. J. Sci., 291, 473-506.

Lanson, B. \& Velde, B. 1992. Decomposition of X-ray diffraction patterns: a convenient way to describe complex I/S diagenetic evolution. Clays Clay Miner., 40, 629-643. 
Lanson, B., Velde, B. \& Meunier, A. 1998. Late-stage diagenesis of illitic clay minerals as seen by decomposition of X-ray diffraction patterns: contrasted behaviours of sedimentary basins with different burial histories. Clays Clay Miner., 46, 69-78.

Lanson, B., Beaufort, D., Berger, G., Bardat, J. \& Lacharpagne, J.-C. 1996. Illitization of diagenetic kaolinite-to-dickite conversion series: late diagenesis of the Lower Permian Roliegend sandstone reservoir, offshore of the Netherlands. J. Sedim. Petrol., 66, 501-518.

Li, G., Mauk, J. L. \& Peacor, D. R. 1995. Preservation of clay minerals in the Precambrian (1.1 GA) Nonesuch Formation in the vicinity of the White Pine copper mine, Michigan. Clays Clay Miner., 43, 361-370.

Mändar, H., Vajakas, T., Felche, J. \& Diennebier, R. 1996. AXES - a program for preparation of parameter input files for FULLPROF. J. Appl. Cryst., 29, 304.

Mens, K. \& Pirrus, E. 1977. Stratotypes of the Cambrian Formations of Estonia. Valgus, Tallinn (in Russian).

Mens, K. \& Pirrus, E. 1997a. Cambrian. In Geology and Mineral Resources of Estonia (Raukas, A. \& Teedumäe, A., eds.), pp. 39-48. Estonian Academy Publishers, Tallinn.

Mens, K. \& Pirrus, E. 1997b. Vendian-Tremadoc clastogenic sedimentation basins. In Geology and Mineral Resources of Estonia (Raukas, A. \& Teedumäe, A., eds.), pp. 184-191. Estonian Academy Publishers, Tallinn.

Moczydłowska, M. \& Vidal, G. 1986. Lower Cambrian acritarch zonation in southern Scandinavia and southern Poland. Geol. Fören. Stockh. Förh., 108, 201-223.

Mokrik, R. 1997. The Palaeohydrogeology of the Baltic Basin: Vendian and Cambrian. Tartu University Press.

Moore, M. D. \& Reynolds, R. C., Jr. 1989. X-ray Diffraction and the Identification and Analysis of Clay Minerals. Oxford University Press.

Morad, S. 1983. Diagenesis and geochemistry of the Visingsö Group (Upper Proterozoic), southern Sweden: a clue to the origin of color differentiation. J. Sedim. Petrol., 53, 51-65.

Osborne, M., Haszeldine, R. S. \& Fallick, A. E. 1994. Variation in kaolinite morphology with growth temperature in isotopically mixed pore-fluids, Brent Group, UK North Sea. Clay Miner., 29, 591-608.

Pearson, M. J. \& Small, J. S. 1988. Illite-smectite diagenesis and paleotemperatures in northern North Sea Quaternary to Mesozoic shale sequences. Clay Miner., 23, 109-132.

Pederstad, K. \& Jørgensen, P. 1985. Weathering in a marine clay during Postglacial time. Clay Miner., 20, 477-491.

Perry, E. A. \& Hower, R. J. 1970. Burial diagenesis in Gulf Coast pelitic sediments. Clays Clay Miner., 18, 165-177.

Pirrus, E. 1970. The distribution of clay minerals of Vendian and Cambrian deposits in East Estonia. Eesti NSV TA Toim. Keem. Geol., 19, 4, 322-333 (in Russian).

Pirrus, E. 1981. Main features of the authigenic mineralization of North Baltic Vendian and Cambrian terrigenous rocks. In Autigennye mineraly terrigennykh otlozhenij Pribaltiki (Pirrus, E., ed.), pp. 5-23. Acad. Sci. ESSR., Tallinn (in Russian).

Pirrus, E. 1983. The role of the palaeogeographic factor in the development of associations of clay minerals in Vendian and Cambrian basins in the North Baltic. In Terrigenous Minerals of the Baltic Sedimentary Rocks (Viiding, H., ed.), pp. 76-91. Inst. Geol., Acad. Sci. ESSR, Tallinn (in Russian).

Pirrus, E. \& Saarse, L. 1979. Geotechnical properties of the Cambrian clays in North Estonia. Eesti NSV TA Toim. Keem. Geol., 28, 2, 68-74 (in Russian). 
Pollastro, R. 1993. Considerations and applications of the illite/smectite geothermometer in hydrocarbon-bearing rocks of Miocene to Mississippian age. Clays Clay Miner., 41, 119133.

Pytte, A. \& Reynolds, R. C., Jr. 1989. The thermal transformation of smectite to illite. In Thermal History of Sedimentary Basins: Methods and Case Histories (Naeser, N. D. \& McCulloh, T. H., eds.), pp. 133-140. Springer-Verlag, New York.

Renac, C. \& Meunier, A. 1995. Reconstruction of paleothermal conditions in a passive margin using illite-smectite mixed-layer series (BA1 scientific deep drill-hole, Ardèche, France). Clay Miner., 30, 107-118.

Reier, A. 1965a. Mineralogical peculiarities of Cambrian clays of the Estonian SSR. Tallinna Polütehnilise Inst. Toim., Ser. A, 221, 3-12 (in Russian).

Reier, A. 1965b. Roentgenographic study of Cambrian clays of the Estonian SSR. Tallinna Polütehnilise Inst. Toim., Ser. A, 221, 13-19 (in Russian).

Reier, A. 1967. Authigenic minerals in clays of the Lontova Formation. Tallinna Polütehnilise Inst. Toim., Ser. A, 246, 19-25 (in Russian).

Reynolds, R. C., Jr. 1985. NEWMOD, a Computer Program for the Calculation of OneDimensional Patterns of Mixed-Layered Clays. R. C. Reynolds Jr., 8 Brook Rd., Hanover, New Hampshire.

Robert, C. \& Chamley, H. 1987. Cenozoic evolution of continental humidity and paleoenvironment, deduced from the kaolinite content of oceanic sediments. Palaeogeogr. Palaeoclimatol. Palaeoecol., 60, 171-187.

Shutov, V. D., Drits, V. A. \& Sakharov, B. A. 1969. On the mechanism of a postsedimentary transformation of montmorillonite into hydromica. Proc. Int. Clay Conf., Tokyo, 523-532.

Środoń, J. 1984. X-ray Powder Diffraction identification of illitic minerals. Clays Clay Miner., 32, 337-349.

Vikulova, M. 1949. A study of clay mineralogy by electron microscope. Sov. Geol., 39, 121-133 (in Russian).

Whitney, G. 1990. The role of water in the smectite to illite reaction. Clays Clay Miner., 38, 343-350.

\title{
SAVIMINERAALIDE DIAGENEETILINE TRANSFORMEERUMINE PÕHJA-EESTI ALAMKAMBRIUMI SAVIKATES SETENDITES
}

\author{
Kalle KIRSIMÄE, Volli KALM ja Per JØRGENSEN
}

On uuritud Põhja-Eesti alamkambriumi Lontova ja Lükati kihistu setendite savimineraalide diageneetilisi muutusi eesmärgiga kirjeldada valdava illitiseerumisega kaasnevaid protsesse. Röntgendifraktsiooniliste meetoditega selgitati illitiseerumisprotsessi tüüpiliste kõrvalsaaduste - raudkloriidi ja mikrokristallilise kvartsi - esinemine savifraktsioonis. Diageneetiliselt moodustunud mineraalide, sh. autigeense kaoliniidi suurem osakaal jämedateralisema lõimisega Lükati kihistus ja Lontova kihistu läänepoolses osas võib olla tingitud meteoorsete vete infiltratsiooni ulatuslikumast mõjust nendele setenditele. 


\title{
ДИАГЕНЕТИЧЕСКИЕ ИЗМЕНЕНИЯ ГЛИНИСТЫХ МИНЕРАЛОВ В НИЖНЕКЕМБРИЙСКИХ ГЛИНИСТЫХ ПОРОДАХ СЕВЕРНОЙ ЭСТОНИИ
}

\author{
КалЛе КИРСИМЯЭ, ВолЛи КАЛМ и Пер ЙЁРГЕНСЕН
}

Исследованы диагенетические изменения глинистых минералов в нижнекембрийских породах люкатиской и лонтоваской свит Северной Эстонии. Помимо главного диагенетического процесса - иллитизации, установлено диагенетическое происхождение Fе-хлорита и микрокристаллического кварца. Обсуждена возможность аутигенного формирования каолинита за счет диагенетического разложения обломочных полевых шпатов и слюд. Обосновано предположение, что на процесс диагенетических изменений пород нижнего кембрия существенное влияние оказала метеорическая инфильтрация вод. 